\title{
Librarians and Technology Skill Acquisition: Issues and Perspectives
}

Libraries are increasingly searching for and employing librarians with significant technology skill sets. This article reports on a study conducted to determine how well prepared librarians are for their positions in academic libraries, how they acquired their skillss and how difficult they are to hire and retain. The examination entails a close look at ALA-accredited LIS program technology course offerings and dovetails a dual survey designed to capture experiences and perspectives from practitioners, both library administrators and librarianss who have significant technology roles.

A recent OCLC report on research libraries, risk, and systemic change discusses what ARL directors perceive as the highest risks to their libraries. ${ }^{1}$ The administrators reported on several high risks in the area of human resources including high-risk conditions in recruitment, training, and job pools. The OCLC report notes that recruitment and retention is difficult due to the competitive environment and the reduction in the pool of qualified candidates. Why precisely do administrators perceive that there is a scarcity of qualified candidates? Changes in libraries, most of which have been brought on by the digital age, are reflected in the need for a stronger technological type of librarianship-not simply because technology is there to be taken advantage of, but because "information" by nature has found its dominion as the supreme commodity perfectly transported on bits. It follows, if information is your profession, you are no longer on paper. That LIS is becoming an increasingly technology-driven profession is both recognized and documented.

A noted trend particularly in academic libraries is a move away from simply redefining traditional or existing library roles altogether in favor of new and completely redesigned job profiles. ${ }^{2}$ This trend verifies actions by library administrators who are increasingly seeking librarians with a wider range of Information Technology (IT) skills to meet the demands of users who are accessing information through technology. Johnson states the need well as

We need an integrated understanding of human needs and their relationships to information systems and social structures. We need unifying principles that illuminate the role of information in both computation and cognition, in both communication and community. We need information professionals who can apply these principles to synthesize human-centered and technological perspectives. ${ }^{4}$

The questions then become, is there a scarcity of qualified individuals to fill these technology-driven librarian roles in our libraries and if so why? How are qualifications acquired and what are are they, besides a moving target? There appears to be two major convergent trends influencing this uncertain phenomenon. The first is what is perceived as "lack of awareness" and consensus about what the core of LIS needs to be or to become in order to offer real value in a constantly changing and competitive information landscape. ${ }^{5}$ The other trend centers on the role of LIS education and the continuing questions regarding its direction, efficacy, and ability to prepare future librarians for the modern information professions of now and the future. While changes are apparent it appears many LIS programs are still operating on a two-track model of "traditional librarians and information managers" and there are enough questions in this area to warrant further investigation and inquiry. ${ }^{6}$

\section{Literature Review}

Most of the literature pertaining to the readiness of librarians to work in increasingly technical environments, centers on LIS education. This certainly makes sense given the assumed qualifications the degree confers. Scant literature focuses solely on the core of the librarians' professional identity, workplace culture, and institutional historical perspectives related to qualifications; however, allusions to "redefining" LIS are often found in LIS education literature. There is limited research on preprofessional or even professional in-service training although calls for such research have been made repeatedly.

A key study on LIS education is the 2000 Kaliper report, issued when the impact of technology in libraries was clearly reaching saturation. ${ }^{7}$ The report is the product of an analysis project with a goal of examining new trends in LIS education. The report lists six trends including three of which are pertinent to the investigation of technology inclusion in LIS programs. These trends note that in 2000, LIS programs were beginning to address a more broad range of information problems and environments, programs were increasing IT content into the curriculum, and several programs were beginning to offer specializations within the curriculum, though not ones with a heavy technology focus. In a widely cited curriculum study in 2004, Markey completed a comprehensive examination of 55

Debra A. Riley-Huff (rileyhuf@olemiss.edu) is Web Services Librarian, University of Mississippi Libraries, University, Miss. Julia M. Rholes (jrholes@olemiss.edu) is Dean of Libraries, University of Mississippi Libraries, University, Mississippi. 
ALA-accredited LIS programs looking for change between the years 2000 and 2002. ${ }^{8}$ Markey's study revealed that while there were improvements in the number of IT-related courses offered and required throughout programs, they were still limited overall with the emphasis continuing to be on the core curriculum consisting of foundations, reference, organization, and management. One of the important points Markey makes is the considerable challenge involved in retraining or acquiring knowledgeable faculty to teach relevant IT courses.

The focus on LIS education issues came to the fore in 2004 when Michael Gorman released a pair of articles asserting that there was a crisis in LIS education, namely an assault on LIS by what Gorman referred to as "Information Science," "Information Studies" and "Information Technology." ${ }^{\prime 9}$ Gorman's papers sought to establish that there is a de facto competition between Information Science courses, which he characterized as courses with a computational focus and LIS courses, which composed core librarianship courses, those tending to be the more user focused and organizational. Gorman claimed LIS faculty were being marginalized in favor of Information Science and made further claims regarding gender roles within the profession along the alleged LIS/IS split. Gorman also noted that there was no consensus about how "librarianship" should be defined coming from either ALA or the LIS graduate programs. The articles were not without controversy, spurring a flurry of discussion in the library community, which spawned several follow up articles. Dillon and Norris rallied against the library vs. information science argument as a premise, which has no bearing on the reality of what is happening in LIS and does nothing but create yet another distracting disagreement over labels. ${ }^{10}$ Others argued for the increasing inclusion of technology courses in LIS education, as Estabrook put it,

Librarianship without a strong linkage to technology (and it's capacity to extend our work) will become a mastodon. Technology without reference to the core library principles of information organization and access is deracinated. ${ }^{11}$

As the future of LIS was being hotly debated, voices in the field were issuing warnings that obstacles were being encountered finding qualified librarians with the requisite technology skills necessary to take on new roles in the library. In 2007, Johnson made the case for the increasing need for new areas of emphasis in LIS, including specializations such as Geographic Information Systems by pointing out that it is not so much the granular training that is expected of LIS education but a higher level technology skill set that allows for the ability to move into these specializations, identify what is needed, assess problems, and make decisions. ${ }^{12}$ In 2006, Neal noted that academic libraries had embarked on an unprecedented increase in filling librarian positions with professionals who do not have a master's degree in library science. ${ }^{13}$ Citing the Association of Research Libraries annual salary statistics, among a variety of positions being filled by other professionals a substantial number are going to those in technology fields such as systems and instructional technology. In the mid 2000s, suggestions that library schools needed to work more closely with computer science departments began coming up more often. Obstacles to these types of partnerships were noted as computer science departments failed to see the advantage offered by library science faculty as well as being wary of taking on a "softening" by the inclusion of what is perceived as a "soft science."14 In response, most library schools have added courses in computing, but many still question the adequacy.

More recently there have been increasing calls from within LIS for more research into LIS education and professional practice. In 2006, a study by McKinney comparing proposed "ALA Core Competencies" to what was actually being taught in ALA-accredited curricula, shed some light on what is currently offered in the core of LIS education..$^{15}$ The study found that the core competency required most often in ALA-accredited programs were "Knowledge Organization" or cataloging (94.6 percent), "Professional Ethics" (80.4 percent), "Knowledge Dissemination" or reference (73.2 percent), "Knowledge Inquiry" or research (66.1 percent), and "Technical Knowledge" or technology foundations (66.1 percent). ${ }^{16}$ These courses map well to ALA Core Competencies but the question in the digital age, is one, not even universally required, technology-related course adequate for a career in LIS? The literature would seem to reflect that it is not.

2007 saw many calls for studies of LIS education using methods that not only examined course curricula but that also sought evidence of outcomes by those working in the field. ${ }^{17}$ An interest in studies reporting on employers' views, graduates' workplace experiences, and if possible longitudinal studies have been outwardly requested. ${ }^{18}$ Indications are that those in library work environments can play a vital role in shaping the future course of LIS education and preprofessional training by providing targeted research, data, and evidence of where weaknesses are currently being experienced and what changes are driving new scenarios. The most current literature points out both areas of technology deficiencies and emerging opportunities in libraries. Areas with an apparent need for immediate improvement are the continuing integration of third-party Web 2.0 application programming interfaces (APIs) and social networking platforms. ${ }^{19}$ Debates about job titles and labels continue but the actuality is that the number of adequately trained digital librarians has not kept up with the demand. ${ }^{20}$ Modern libraries require those in technology-related roles to have broad or 
specialized competencies in areas such as web development, database design, and management paired with a good working knowledge of classification formats such as XML, MARC, EAD, RDF and Dublin Core. Educational technology (ET) has been identified as an area of expected growth opportunity for libraries and there have been suggestions that more LIS programs should partner with ET programs to improve LIS technology offerings, skills and preprofessional training. ${ }^{21}$

LIS program change, including the apparent coalescing of information technology focused education would appear to be demonstrated by the iSchool or iField Caucus of ALA accredited programs, however the literature is not clear on if that is actually being evidenced. The iSchools organization started in as collective in 2005 with a goal of advancing information science. iSchools incorporate a multidisciplinary approach and those with a library science focus are ALA accredited. ${ }^{22}$ A 2009 study interestingly applied Abbott's theoretical framework used in the Chaos of Disciplines to the iField. ${ }^{23}$ Resulting in abstract yet relevant conclusions, Abbott looks at change in a field through a sociological lens looking for patterns of fractal distinction over time. The study concluded that traditional LIS education remained at the heart of the iField movement and that the real change has been in locale, from libraries to location independent. ${ }^{24}$ Hall's 2009 study exploring the core of required courses across almost all ALA accredited programs reveals that the core curriculum is still principle-centered, but it is focusing less on reference and intermediary activities with a definite shift toward research methods and information technology. ${ }^{25}$

\section{Method}

This research study was designed to capture a broad view of technology skill needs, skill availability, and skill acquisition in libraries, while still allowing for some areas of sharper focus on stakeholder perspectives. The four primary stakeholder groups in this study were identified as LIS educators, LIS students, working librarians, and library administrators. The research questions cover three main areas of technology skill acquisition and employment. One area is LIS education and whether the status of all technology course offerings has changed in recent years in response to market demands. The second area is the experience of librarians with significant technology roles with regards to job availability, readiness, and technology skill acquisition. The third area is, the perception of library administrators regarding the availability and readiness of librarians with technology roles. To cover the research questions and provide a broad situational view, the research was triangulated and aimed at the three question areas. Data collection was accomplished by examination of course catalogs and surveys of both library administrators and technology librarians.

The LIS educational data was obtained by inspecting course catalogs. Course catalogs and website curriculum pages from all ALA-accredited LIS programs in the United States, Canada, and Puerto Rico were examined in December 2009 for the inclusion of technology-related courses. The catalogs examined were for the 2009-10 academic year. Spanish and French catalogs were translated. Each available course description was reviewed and those courses with a primary technology component were identified. In a secondary examination the selected courses were closely inspected for the exact technology focus and the primary subject content was noted for each course. Courses were then separated into categories by areas of focus and tabulated.

A targeted survey identified practicing technology librarians' perspectives on their level of preparation and continuing skill level needs based on actual job demands. In this survey, librarians with significant technology roles was defined as "for the purposes of this survey a librarian with a significant technology role would be any librarian whose job would very likely be considered "IT" if they were not in a library and whose job titles contain words like "systems, digital, web, electronic, network, database, automation, and whose job involves maintaining and/or building various IT infrastructures." The survey was posted on various library and library technology electronic discussion lists in December 2009 and was available for two weeks. Library administrative perspectives were also gained through a targeted survey aimed at those with an administrative role of department head or higher. The survey was designed to capture the reported experience library administrators have had with librarians in significant technology roles, primarily as it relates to skill levels, availability, hiring, and retention. This survey was posted on to various library administrative and technology discussion lists in December 2009 and was also available for two weeks. Both surveys included many similar questions to compare and contrast viewpoints. Results were tabulated to form an overarching picture and some relevant comparisons were made.

There are limitations and inherent issues with this type of research. Catalog examinations when completed by qualified librarians can hold great accuracy; however, the introduction of bias or misinterpretation is always possible. ${ }^{26}$ When categorizing courses, the authors reviewed course descriptions three separate times to ensure accuracy. Courses in doubt were reviewed again with knowledgeable colleagues to obtain a consensus. Surveys designed to capture perspectives, views, and experiences are by nature highly subjective and provide data that is both qualitative and quantitative. Tabulated data was given strictly simple numerical representation to provide a factual picture of what was reported. 
Additionally, although the librarian survey was targeted to "those with significant technology roles," it would appear that the definition of "significant" seemed to vary in interpretation by the respondents. This is discussed in further detail in the findings. Given the limitations of this type of research, the authors did not attempt to find definite correlations, however trends and patterns are clearly revealed.

\section{Catalog Findings}

Course catalogs from all 57 ALA-accredited programs in the United States, Canada, and Puerto Rico were examined for the inclusion of technology-related courses. A total of 439 technology-related courses were offered across the 57 LIS programs, including certificate program course offerings. The total number of technology-related courses offered by program ranged from 2 to 20 . The mean number of courses offered per program was 7.7, the median was 10 , and the mode was 4 . Table 1 shows the total number of technology courses being offered per program by matching them with the number of courses they offer.

Catalog course content descriptions were analyzed looking for a technology focus. The fifteen categories noted in table 2 were selected as representative of the technology-related courses offered. It is acknowledged that some course content may be overlapping, but each course was placed in only one category based on its primary content. Note also the inclusion of "metadata markup" which may arguably be considered description or cataloging. Metadata was included because it is an integral part of many new digital services. The categories are presented in column 1, the total number of courses offered is presented in column 2. The number of advanced courses available within each category total is further broken out into parenthesis. Some programs offered more than one course in a given category; hence the percentage of programs offering at least one course is given in column 3.

Table 1. Number of technology-related courses being offered per program

\begin{tabular}{ll}
\hline \# of Programs Offering & \# of Courses Offered \\
\hline 1 offers & 2 courses \\
6 offer & 3 courses \\
8 offer & 4 courses \\
6 offer & 5 courses \\
7 offer & 6 courses \\
5 offer & 7 courses \\
5 offer & 8 courses \\
1 offer & 9 courses \\
6 offer & 10 courses \\
1 offers & 11 courses \\
3 offer & 12 courses \\
2 offer & 13 courses \\
2 offer & 14 courses \\
1 offers & 15 courses \\
1 offers & 17 courses \\
1 offers & 18 courses \\
1 offers & 20 courses \\
\hline
\end{tabular}

Table 2. Course content description and number of courses offered across all programs. The number of advanced courses in the total is given in parenthesis.

\begin{tabular}{|c|c|c|}
\hline Web Architecture (Web design, development, usability) & $52(11)$ & 68 \\
\hline Broad technology survey courses (basics of library technologies and overviews) & 50 & 65 \\
\hline Digital Libraries & $43(4)$ & 61 \\
\hline Metadata Markup (DC, EAD, XML, RDF) & $43(10)$ & 50 \\
\hline Digital imaging, audio and video production & $33(5)$ & 47 \\
\hline Automation and Integrated Library Systems & 21 & 37 \\
\hline Networks & $32(3)$ & 35 \\
\hline Human Computer Interaction & $21(4)$ & 29 \\
\hline Instructional Technology & 12 & 21 \\
\hline Geographic Information Systems & $6(1)$ & 8 \\
\hline
\end{tabular}




\section{Demographic Data}

Table 3. Response data

\begin{tabular}{|c|c|c|}
\hline Responses & $\begin{array}{l}\text { Administrative } \\
\text { Survey }\end{array}$ & $\begin{array}{l}\text { Librarian } \\
\text { Survey }\end{array}$ \\
\hline Total responses & 185 & 382 \\
\hline $\begin{array}{l}\text { Total usable } \\
\text { (qualified) }\end{array}$ & 146 & 227 \\
\hline By type & $\begin{array}{l}\text { Administrative } \\
\text { Survey }\end{array}$ & $\begin{array}{c}\text { Librarian } \\
\text { Survey }\end{array}$ \\
\hline Under 5,000 & 37 & 72 \\
\hline $5,000-10,000$ & 25 & 31 \\
\hline $10,000-15,000$ & 18 & 28 \\
\hline $15,000-20,000$ & 11 & 20 \\
\hline $20,000-25,000$ & 13 & 21 \\
\hline $25,000-30,000$ & 16 & 13 \\
\hline $30,000-35,000$ & 4 & 11 \\
\hline $35,000-40,000$ & 5 & 9 \\
\hline More than 40,000 & 12 & 21 \\
\hline Unknown & 5 & 1 \\
\hline
\end{tabular}

An assessment of the course catalog facts reveals that there have been increases in the number of technology courses offered in LIS programs, but is it enough? Significant longitudinal data shows an increased emphasis in the area of metadata. A 2008 study of the total number of LIS courses offering Internet or electronic resources and metadata schemas, found that the number of programs offering such as being ten (17.5 percent) with only twelve metadata courses offered in total. ${ }^{27}$ Current results show 43 metadata courses offered with 50 percent of LIS programs offering at least one course. The lack of a solid basis in web 2.0 applications and integration as reported by Aharony is confirmed by the current catalog data, with only 17 percent of programs offering a course. ${ }^{28}$

While at first glance it looks like many technology-related courses are currently being offered in LIS programs, a closer inspection reveals cause for concern. Many of these courses should be offered by 100 percent of LIS programs and advanced courses in many areas should be offered as well. While there may be some overlap of content in some of these course descriptions, the percentages are still too low to deduce that LIS graduates, without preprofessional technology experience or education, are really prepared to take on serious technology roles in academic libraries.
Table 5. Respondent type

\begin{tabular}{lc}
\hline Administrative Survey: Position & \# of Responses \\
\hline Dean, Director, University Librarian & 46 \\
Department Head & 71 \\
Manager or other leadership role & 29 \\
\hline Librarian Survey: General area & \# of Responses \\
of work & 48 \\
\hline Public Services & 42 \\
Systems & 32 \\
Web Services & 31 \\
Reporting dual roles & 29 \\
Digital Librarian & 28 \\
Electronic Resources Librarian & 18 \\
Emerging/lnstructional & 10 \\
Technologies & 9 \\
Administrative & 7 \\
Metadata/Cataloger & 4 \\
Technical Services & \\
Distance Education Librarian &
\end{tabular}

\section{Perspectives on Job Availability, Readiness and Skill Acquisition}

As previously noted in the method, two surveys were administered to collect participant viewpoint data pertinent to the study. Reponses were carefully checked to determine whether they met the criteria for inclusion in the study. No attempt was made to disqualify respondents based solely on job title. It did appear that a significant number of non-target subjects did initially reply to the librarian survey, but quit the survey at the technology-related questions. Final inclusion was based on either an IT-related job title or if the respondent answered the technology questions regardless of job title. Tables 3-5 report demographic response data.

\section{Perspectives on Job and Candidate Availability}

A 2009 study by Matthew and Pardue asked the question "What skills do librarians need in today's world?" 29 They sought to answer this question by performing a content analysis, spread over five months, of randomly selected jobs from ALA's JobList. What they found in the area of technology was a significant need for web development, 
Table 6. Administrative report on positions open, searches and difficulty of search $(n=145)$

\begin{tabular}{lcc}
\hline Position Classification & Searches & $\begin{array}{c}\text { Search } \\
\text { Difficulty }\end{array}$ \\
\hline $\begin{array}{l}\text { Systems/ Automation } \\
\text { Librarian }\end{array}$ & 40 & 2.78 \\
Digital Librarian & 32 & 2.6 \\
$\begin{array}{l}\text { Emerging \& Instructional } \\
\text { Technology Librarian }\end{array}$ & 15 & 2.53 \\
$\begin{array}{l}\text { Web Services/ Development } \\
\text { Librarian }\end{array}$ & 33 & 2.51 \\
$\begin{array}{l}\text { Electronic Resources } \\
\text { Librarian }\end{array}$ & 22 & 1.95 \\
$\begin{array}{l}\text { Database Manager } \\
\text { Network Librarian/ }\end{array}$ & 1 & na \\
Professional & 1 & na \\
\hline
\end{tabular}

project management, systems development, and systems applications. Further they suggest that some librarians are using a substantial professional IT skills subset.

This article's literature review points out that there are assertions being made that some technology-related librarian positions are difficult to fill and may in fact be filled by non-MLS professionals. In the associated surveys the authors sought to capture data related to actual job availability, search experiences and perspectives by both library administration and librarians. Note that both MLS librarians and a few professional library IT staff completed the survey. The distinction is made where appropriate.

The survey asked library administrators if they had hired a technology professional position in the past five years. 146 responses were received and 100 respondents indicated that they had conducted such a search, with the total number of searches being reported at 167 . Of these searches, 22 did not meet the criteria for inclusion due to other missing data such as job title. The total reported number of librarian/professional level technology positions that were posted for hire by these respondents was 145 with some respondents reporting multiple searches for the same or different positions. Respondents conducting searches reported having between 1 and 5 searches total with the average number being 1.45 per respondent.

The respondents were also asked to provide the position title for each search, the difficulty encountered in conducting the search, and the success rate. Job titles were divided into categories to ascertain how many positions in each category reported having a relevant search conducted. Each search was then assigned a point value
Table 7. Librarian report on positions held or current searches and difficulty $(n=316)$

\begin{tabular}{lcc}
\hline Position Classification & $\begin{array}{c}\text { \# of } \\
\text { Positions/ } \\
\text { Searches }\end{array}$ & $\begin{array}{c}\text { Search } \\
\text { Difficulty }\end{array}$ \\
\hline Administrative & 8 & 3 \\
Technical Services & 17 & 2.11 \\
Public Services & 57 & 2.1 \\
$\begin{array}{l}\text { Systems/ Automation } \\
\text { Librarian }\end{array}$ & 76 & 1.89 \\
Web Services/ & 38 & 1.89 \\
$\begin{array}{l}\text { Development Librarian } \\
\text { Electronic Resources }\end{array}$ & 39 & 1.87 \\
Librarian & 41 & 1.8 \\
Digital Librarian & 13 & 1.77 \\
Metadata/Cataloger & & 1.66 \\
Distance Education & 6 & 1.61 \\
Librarian & & na \\
Emerging \& Instructional & 21 & \\
Technology Librarian & 30 & \\
Reporting dual roles & & \\
\hline
\end{tabular}

based on the difficulty rating and the classifications were then averaged by difficulty. Some respondents were unsure of difficulty ratings because the searches happened before their presence at their current library and those searches were excluded. Position classifications with less than five searches were excluded from averaging and are marked "na" in table 6. The difficulty rubric is as follows: 1 = easy; 2 = not too bad, pretty straightforward search; 3 = a bit tough, the search was protracted; 4 $=$ very difficult, required more than one search; $5=$ unable to fill the position. It is to be noted that almost all levels of difficulties were reported for many classifications but that the overall average hiring difficulty rating was 2.48.

A comparable set of questions was posted to the librarian survey. We asked librarians to report professional level technology positions they had held in the past five years along with any current job searches. 164 responses were received by people indicating that they had held such a position or were searching for one, with the total number of positions/searches being reported at 316 with some respondents reporting multiple positions. Respondents reported having between one and five different positions with the average number being 1.92 jobs per respondent (see table 7).

The respondents were also asked to give the position title for each position held or positions they were applying for as well as the difficulty encountered in obtaining the position. Like the administrative report, job titles were 
divided into categories to ascertain how many positions in each classification category. Each position classification was then assigned a point value base on how the respondents rated the difficulty of those particular searches and the classifications were then averaged by difficulty using the same scale that was applied in the administrative survey. Again, almost all levels of difficulties were reported for many classifications but that the overall average hiring difficulty rating was 1.9 .

To provide as accurate a picture as possible the surveys asked both groups to indicate if any well known mitigating factors contributed to complications with the job searches. These factors are shown in Table 8 which stacks both groups for comparison.

This particular dataset reveals some interesting patterns. Those roles that were in the most demand were the also the most difficult to hire for, while these also were the easier positions for candidates to find. Librarians also listed more job categories as having a significant technology component than the administrators had. Perhaps most notable is the discrepancy shown between how administrators perceive the qualifications of candidates as compared to how candidates view themselves. While both groups acknowledge lack of IT skills and qualifications as the number one mitigating factor, library administrators perceive the problem as being significantly more serious. This data backs up other recent findings that important new job categories are being defined in LIS. ${ }^{30}$ The data also further support that these roles, while centering on core librarianship principles, have a different skill set. ${ }^{31}$

\section{Job Readiness Perspectives}

Issues of job readiness for academic librarians need to be looked at from a number of different perspectives. Job readiness can be understood in one way by a candidate and can be something different to an employer. Job readiness is not only of critical concern at the beginning of a librarian's career, clearly this attribute continues to be significant throughout an individual's length of service in one or more roles and to one or more employers. Job readiness is composed of several factors, the most important being education, experience and ongoing skill acquisition. While this is certainly true for all librarians it is of even more concern to those librarians with significant technology roles because of rapid changes in technology.

A concern has been established in the literature and in this study that LIS education, in the areas of technology, may be inadequate and lack the intensity necessary for modern libraries. This perception has been backed up by entrants to the profession. ${ }^{32}$ That technology skills are extremely important to library employers has been evident for at least a decade. In 2001 a case study on
Table 8. Mitigating factors in hiring and job search $(n=93)$

\begin{tabular}{|c|c|}
\hline $\begin{array}{l}\text { Administrative Survey: Mitigating } \\
\text { factors in hiring as a percentage of } \\
\text { respondents to the question }(n=93)\end{array}$ & $\begin{array}{c}\% \text { of } \\
\text { Responses }\end{array}$ \\
\hline $\begin{array}{l}\text { We had difficulty getting an applicant } \\
\text { pool with adequate skills }\end{array}$ & 54 \\
\hline $\begin{array}{l}\text { We are unable to offer qualified } \\
\text { candidates what we feel is a competitive } \\
\text { salary. }\end{array}$ & 38 \\
\hline $\begin{array}{l}\text { We are located in what may reasonably } \\
\text { be perceived as an undesirable area to } \\
\text { live. }\end{array}$ & 23 \\
\hline $\begin{array}{l}\text { We are located in an area with a very } \\
\text { high cost of living. }\end{array}$ & 23 \\
\hline $\begin{array}{l}\text { We have an IT infrastructure or } \\
\text { environment that we and/or a candidate } \\
\text { may have perceived as unacceptable. }\end{array}$ & 20 \\
\hline $\begin{array}{l}\text { The current economic climate has made } \\
\text { hiring for these types of positions easier. }\end{array}$ & 18 \\
\hline $\begin{array}{l}\text { A successful candidate did not accept } \\
\text { an offer of employment }\end{array}$ & 13 \\
\hline $\begin{array}{l}\text { Librarian Survey: Mitigating factors } \\
\text { in job search as a percentage of } \\
\text { respondents to the question }(n=198)\end{array}$ & $\begin{array}{l}\% \text { of } \\
\text { responses }\end{array}$ \\
\hline $\begin{array}{l}\text { I suspect I may not have/had adequate } \\
\text { skills, experience or I was otherwise } \\
\text { unqualified. }\end{array}$ & 25 \\
\hline $\begin{array}{l}\text { I have not been able to find a position } \\
\text { for what I consider to be a fair salary. }\end{array}$ & 11 \\
\hline $\begin{array}{l}\text { Many jobs are located in what may } \\
\text { reasonably be perceived as an } \\
\text { undesirable area to live. }\end{array}$ & 10 \\
\hline $\begin{array}{l}\text { Many jobs are located in an area with a } \\
\text { very high cost of living. }\end{array}$ & 15 \\
\hline $\begin{array}{l}\text { Some jobs have an IT infrastructure or } \\
\text { environment that I have perceived as } \\
\text { unacceptable. }\end{array}$ & 10 \\
\hline $\begin{array}{l}\text { The current economic climate has now } \\
\text { made finding these types of positions } \\
\text { tougher. }\end{array}$ & 22 \\
\hline $\begin{array}{l}\text { I was a successful candidate but I } \\
\text { could or did not accept an offer of } \\
\text { employment. }\end{array}$ & 3 \\
\hline
\end{tabular}

employment status for "newly minted" MLS graduates having just entered the profession were asked in a survey "Did specific information technology or computer skills lead to you getting a job?" the answer was a "resounding yes" by 66 percent of the respondents. ${ }^{33}$ Experience is 
Table 9. Question sets related to experience factors by group

\begin{tabular}{|c|c|c|c|c|c|}
\hline Administrative Survey & $\begin{array}{l}\text { Strongly } \\
\text { Disagree }\end{array}$ & Disagree & Can't say & Agree & $\begin{array}{l}\text { Strongly } \\
\text { Agree }\end{array}$ \\
\hline $\begin{array}{l}\text { New librarians right out of graduate school seem } \\
\text { to be adequately prepared }(n=111)\end{array}$ & $7 \%$ & $40 \%$ & $24 \%$ & $28 \%$ & $1 \%$ \\
\hline $\begin{array}{l}\text { Librarians with undergraduate or } 2 \text { nd graduate } \\
\text { degrees in a technology/computer fields seem } \\
\text { adequately prepared }(n=109)\end{array}$ & $1 \%$ & $9 \%$ & $48 \%$ & $39 \%$ & $4 \%$ \\
\hline $\begin{array}{l}\text { Librarians with some (up to } 3 \text { years) post MLS } \\
\text { technology experience seem adequately prepared } \\
\text { ( } n=111)\end{array}$ & $1 \%$ & $10 \%$ & $17 \%$ & $62 \%$ & $10 \%$ \\
\hline Librarian Survey & $\begin{array}{l}\text { Strongly } \\
\text { Disagree }\end{array}$ & Disagree & Other & Agree & $\begin{array}{l}\text { Strongly } \\
\text { Agree }\end{array}$ \\
\hline $\begin{array}{l}\text { As a new librarian right out of graduate school I } \\
\text { was adequately prepared }(n=187)\end{array}$ & $12 \%$ & $19 \%$ & $\begin{array}{l}\text { No grad } \\
\text { degree } \\
3 \%\end{array}$ & $42 \%$ & $8 \%$ \\
\hline $\begin{array}{l}\text { I have an undergraduate or } 2 \text { nd graduate degree } \\
\text { in a technology/computer field that has helped me } \\
\text { be adequately prepared }(n=187)\end{array}$ & $13 \%$ & $7 \%$ & $\begin{array}{l}\text { No tech } \\
\text { degree } \\
60 \%\end{array}$ & $13 \%$ & $6 \%$ \\
\hline $\begin{array}{l}\text { I had pre-professional technology-related } \\
\text { experience that helped me be adequately } \\
\text { prepared }(n=187)\end{array}$ & $3 \%$ & $7 \%$ & $\begin{array}{l}\text { No such } \\
\text { experience } \\
20 \%\end{array}$ & $43 \%$ & $27 \%$ \\
\hline $\begin{array}{l}\text { I have never felt like I am adequately prepared for } \\
\text { technology roles }(n=186)\end{array}$ & $19 \%$ & $43 \%$ & $\begin{array}{l}\text { Neutral } \\
23 \%\end{array}$ & $12 \%$ & $2 \%$ \\
\hline
\end{tabular}

also a very important factor, with one study of academic library search committees reporting committee members mentioning that "experience trumps education." 34

This study sought to gather data on possible patterns in the job readiness area. The authors wanted to know how job candidates and employers felt about the viability of new MLS graduates, how experience factored into job readiness, how much experience is out there and how long term experience impacted expectations.

The survey asked administrators how many years of library technology experience they preferred from a candidate. There were 97 responses; the range of preferred experience was $0-7$, the mean was 3.06, and the mode was 3. Librarians were also asked how much experience they had in a technology-related library role. There were 187 responses; the range of experience was 0-39 years, the mean was 8.7 , the mode was 5 . When participating administrators were asked if they felt it was necessary to have an MLIS librarian fill a technology-related role that is heavily user-centric, 110 administrators responded. 
Table 10. Education and skill supplementation for librarians with technology roles

Administrative Survey: In what ways have you supplemented training for your librarians or professional staff with technology-related roles? (Does not include ALA conferences)

We have paid for technology-related conferences and pre-conferences.

We have paid for or allowed time off for classes.

We have paid for or allowed time for off online workshops and /or tutorials

We have paid for books or other learning materials.

We have paid for some or all of a 1 st or 2 nd graduate degree.

We would like to supplement but it is not in our budget.

We feel that keeping up with technology is essential for librarians with technology-related roles.

Librarian Survey: In what ways have you supplemented your own education related to technology skill development in terms of your time and/or money? (Not including ALA conferences)

I have attended technology-related conferences and pre-conferences.

I have taken classes.

I have taken online workshops and/or tutorials

I have bought books or other learning materials.

I am getting a 1st or 2nd graduate degree.

We would like to supplement my own education but I can not afford it.

I would like to supplement my own education but I do not have time.

I have not had to supplement in any way.

I feel that keeping up with technology is essential for librarians with technology-related roles.

Responses ranged from 50 percent "Yes," 38 percent "No," and 12 percent "Unsure." To the same question, 195 practicing technology librarians responded with 58 percent "Yes," 23 percent "No," and 20 percent "Unsure." The administrator participants were asked if they had ever had to fill a technology-related librarian role with a non-MLS hire simply because they were unable to find a qualified librarian to fill the job. Of 106 responses, 22 percent reported that they hired a non-MLS candidate. The librarian participants were also was asked to report on MLS status; out of 194 responses, 93 percent reported holding an MLS or equivalent. The survey also asked the librarian participants to report what year they graduated from their MLS program as the authors felt this data was important to the inherent longitudinal perspectives reported in the study. Of 162 responses, participants reported graduating between 1972-2009. The mean was 1999 , the median was 2002, and the mode was 2004. Table 9 shows a question set related to experience factors, which stacks both groups for comparison.

There are a few notable points in this particular dataset including what appears to be an area of disagreement between administrators and librarians about the readiness of new librarians and the value of related technology degrees. Areas of agreement are noted in the importance of preprofessional experience, three or more years of experience, and the generally positive attitude regarding librarians' ability to successfully take on significant technology roles in libraries.

\section{Ongoing Skill Acquisition and Retention}

How librarians with significant technology roles acquire the skills needed to do their jobs and how they keep those skills current was of great interest in this study. The importance of preprofessional experience has been noted but we should also include the value of service learning in LIS education as an important starting point. Successful service learning experiences include practicum and partnerships with libraries in need of technology-related services. Successful projects such as online exhibits, wireless policies, taxonomy-creation and cross-walking for CONTENTdm are just a few of the service projects that have given LIS students real-world experience. ${ }^{35}$ This 
Table 11. Role transformation from traditional library roles to technology centric roles and the reverse.

\begin{tabular}{|c|c|}
\hline Administrative Survey $(n=104)$ & $\%$ \\
\hline We have had one or more librarians attempt this transformation with some success. & 35 \\
\hline Some have been interested in doing this but have not done so. & 14 \\
\hline We do not seem to have had anyone interested in this & 11 \\
\hline Librarian Survey $(n=184)$ & $\%$ \\
\hline I started out in a technology-related librarian role and I am still in it. & 45 \\
\hline I have made a complete technology role transformation successfully from another type of librarian role. & 30 \\
\hline I am not a librarian. & 4 \\
\hline
\end{tabular}

research study asked administrators and librarians in what formal ways they supplement their ongoing education and skill acquisition. Table 10 shows these results in a stacked format for comparison.

Also of interest in this data set is the higher level of importance librarians place on continuing skill development in the area of technology. In open ended text responses a number of librarians reported that the less formal methods of monitoring electronic discussion lists and articles was also a very important part of keeping up with technology in their area. The priority of staying educated, active and current for librarians with significant technology roles cannot be underestimated; what Tennant defines as technology agility,

\footnotetext{
The capacity to learn constantly and quickly. I cannot make this point strongly enough.

It does not matter what they know now. Can they assess a new technology and what it may do (or not do) for your library? Can they stay up to date? Can they learn a new technology without formal training? If they can't they will find it difficult to do the job. ${ }^{36}$
}

Not all librarians with technology roles start out in those positions and thus role transformation must be examined. In some cases librarians with more traditional roles such as reference and collection development have transformed their skill set and taken on technology centric roles. Table 11 shows the results of the survey questions related to role transformation in a stacked format for comparison.

To be noted in this data set is the large number of librarians who have transitioned successfully into technology centric roles. This supports the perception that experience and on the job learning play a leading role in the development of technology skills for librarians. Openended survey comments also revealed a number of staff who initially were hired in an IT role and then went on to acquire an MLS while continuing in their technologyfocused role.

Retention is sometimes problematic for librarians with IT roles, primarily because many of them are also employable in many other settings apart from libraries. The survey asked administrators "Do you know any librarians with technology roles that have taken IT positions outside the library field?" and out of 111 respondents, 33 percent answered "yes." In open-ended responses the most common reasons administrators felt retention may be a problem was salary, lack of challenges/opportunities, and risk averse cultures. The survey also asked the librarian group "Do you think you would ever consider taking an IT position outside the library field?" Out of 190 respondents; 34 percent answered "yes," 23 percent "yes, but only if it was education related," and 42 percent "no." Additionally 38 percent of these librarian respondents knew a librarian who took an IT position outside the library field. For the librarian participants an open response field in the survey, named work environment and lack of support for technology as the most often named reasons for this leaving a position.

The surveys used in this research study covered several complicated issues. Those who responded to the surveys were encouraged to leave open text comments 
Table 12. A sample of open ended responses from the two surveys

\section{Administrative Survey}

"There is a huge need for more and adequate technology training for librarians. It is essential for libraries to remain viable in the future."

"Only one library technology position (coordinator) is a professional librarian. Others are professional positions without MLS."

"There is a lot of competition for few jobs, especially in the current economic climate."

"We finally hired at the level of technician as none of the MLS candidates had the necessary qualifications."

"If I wanted a position that would develop strategy for the library's tools on the web or create a digitization program for special collections, I probably would want an MLS with library experience simply because they understand the expectations and the environment."

"Number of years of experience in technology is not as important as a willingness to learn and keep current. Sometimes old dogs won't move on to new tricks. Sometimes new dogs aren't interested in learning tricks."

\section{Librarian Survey}

"I believe that because technology is constantly changing and evolving, librarians in technology-oriented positions must do the same."

"My problem with being a systems librarian in a small institution is that the job was $24 / 7 / 365$. Way too much stress with no down time."

“I have left the library field for a few years but came back. My motivation was a higher salary, but that didn’t really happen."

"I'm considering leaving my current position because the technology role (which I do love) was added to my position without much training or support. Now that part of my job is growing so that I can't keep up with all my duties."

"I don't think that library school alone prepared me for my job. I had to do a lot of external study and work to learn what I did, and worked as a part-time Systems Library Assistant while in school, where I learned the majority of what prepared me for my current job."

"Library Schools need to be more rigorous about teaching students how to innovate with technology, not just use tools others have built. You can't convert "traditional" librarians into technology roles without rigorous study. Otherwise, you will get mediocre and even dangerous results."

in several key areas. A large number of comments were received and many of them were of considerable length. Many individuals clearly wanted to be heard, others were concerned their story would not be captured in the data, and many expressed a genuine overall interest in the topic. A few salient comments from a variety of areas covered are given in table 12.

\section{Conclusion}

This study seeks to provide an overview of the current issues related to IT staffing in academic libraries by reporting on three areas dealing with library skill acquisition and employment. With regards to the status of technology course offerings in LIS programs, there has been a significant increase in the number of technologyrelated courses, but the numbers of technology courses vary considerably from program to program and the content of individual courses appears to vary considerably as well. There appears to be a clear need for additional courses at a more advanced level. This need is evidenced by the experiences of both information technology job candidates and the administrators involved in the hiring decisions. There are clearly still difficulties in both the acquisition of needed skill sets for certain positions and in actual hiring for some information technology positions.

There are also some discrepancies between how administrators perceive candidates' qualifications as compared to how the candidates view themselves. Administrators perceive the problem of a lack of IT skills/qualifications as more serious than do candidates. The two groups also differ on the question of "readiness" of new professionals. The two groups do agree on the importance of preprofessional experience, and they both exhibit generally positive attitudes toward librarians' ability to successfully take on significant technology roles in libraries. 
More research is still needed to identify the key technology skills needed. Case studies of successful library technology teams and individuals may reveal more about the process of skill acquisition. Questions regarding how much can be taught in LIS courses or practicum, and how much must be expected through on-the-job experience are good areas for more research.

\section{References}

1. James Michalko, Constance Malpas and Arnold Arcolio, "Research Libraries, Risk and Systematic Change," OCLC Research (Mar. 2010), http://www.oclc.org/research/publications/ library/2010/2010-03.pdf.

2. Lori A. Goetsch, Reinventing Our Work, "New and Emerging Roles for Academic Librarians," Journal of Library Administration 48, no. 2 (2008): 157-72.

3. Janie M. Mathews and Harold Pardue, "The Presence of IT Skill Sets in Librarian Position Announcements," College and Research Libraries 70, no. 3 (2009): 250-57.

4. Peggy Johnson, "From the Editor's Desk," Technicalities 27, no. 3 (2007): $2-4$.

5. Ton deBruyn, "Questioning the Focus of LIS Education," Journal of Education for Library \& Information Science 48, no. 2 (2007): 108-15.

6. Jacquelyn Erdman, "Education for a New Breed of Librarian," Reference Librarian 47, no. 98 (2007): 93-94.

7. "Educating Library and Information Science Professionals for a New Century: The KALIPER Report," Executive Summary. ALIPER Advisory Committee, ALISE. (Reston, Virginia, July 2000), http://www.si.umich.edu/ durrance/TextDocs / KaliperFinalR.pdf (accessed June 1, 2010).

8. Karen Markey, "Current Educational Trends in Library and Information Science Curricula," Journal of Education for Library and Information Science 45, no. 4 (2004): 317-39.

9. Michael Gorman, "Whither library education?" New Library World 105, no. 9/10 (2004): 376-80; Michael Gorman, "What Ails Library Education?" Journal of Academic Librarianship 30, no. 2 (2004): 99-101.

10. Andrew Dillon and April Norris, "Crying Wolf: An Examination and Reconsideration of the Perception of Crisis in LIS Education," Journal of Education for Library \& Information Science 46, no. 4, (2005): 208-98.

11. Leigh S. Estabrook, "Crying Wolf: A Response," Journal of Education for Library E Information Science 46, no. 4 (2005):299-303.

12. Ian M. Johnson, "Education for Librarianship and Information Studies: fit for purpose?" Information Development 23, no.1 (2007): 13-14

13. James G. Neal, "Raised by Wolves," Library Journal 131, no. 3 (2006): 42-44.

14. Sheila S. Intner, "Library Education for the Third Millennium," Technicalities 24, no. 6 (2004): 10-12

15. Renee D. McKinney, "Draft Proposed ALA Core Competencies Compared to ALA-Accredited, Candidate, and Precandidate Program Curricula: A Preliminary Analysis," Journal of Education for Library E Information Science 47 no.1 (2006): 52-77.
16. Ibid., 53-54.

17. Thomas W. Leonhardt, "Thoughts on Library Education," Technicalities 27, no. 3 (2007): 4-7.

18. Thomas W. Leonhardt, "Library and Information Science Education" Technicalities 27, no. 2 (2007): 3-6.

19. Noa Aharony, "Web 2.0 in U.S. LIS Schools: Are They Missing the Boat?" Ariande 30, no. 54 (2008): 1

20. Chuck Thomas and Salwa Ismail Patel, "CompetencyBased Training for Digital Librarians: A Viable Strategy for an Evolving Workforce?" Journal of Education for Library $\mathcal{E}$ Information Science, 49, no. 4 (2008): 298-309.

21. Michael J. Miller, "Information Communication Technology Infusion in 21st Century Librarianship: A Proposal for a Blended Core Course," Journal of Education for Library $\mathcal{E}$ Information Science 48, no. 3 (2007): 202-17.

22. "About the iSchools." (2010); http://www.ischools.org/ site/about/ (accessed 9/1/2010).

23. Laurie J. Bonnici, Manimegalai M. Subramaniam, and Kathleen Burnett, "Everything Old is New Again: The Evolution of Library and Information Science Education from LIS to iField," Journal of Education for Library E Information Science 50, no. 4 (2009): 263-74; Andrew Abbott, The Chaos of Disciplines (Chicago: Chicago Univ. Pr., 2001).

24. Bonnici, "Everything Old is New Again," 263-74.

25. Russell A. Hall, "Exploring the Core: An Examination of Required Courses in ALA-Accredited," Education for Information 27 , no. 1 (2009): 57-67.

26. Ibid., 62 .

27. Jane M. Davis, "A Survey of Cataloging Education: Are Library Schools Listening?" Cataloging \& Cataloging Quarterly 46, no. 2 (2008): 182-200.

28. Aharony, "Web 2.0 in U.S. LIS," 1.

29. Janie M. Mathews and Harold Pardue, "The Presence of IT Skill Sets in Librarian Position Announcements," College $\mathcal{E}$ Research Libraries 70, no. 3 (2009): 250-57.

30. "Redefining LIS Jobs," Library Technology Reports 45, no. 3, (2007): 40.

31. Youngok Choi and Edie Rasmussen, "What Qualifications and Skill are Important for Digital Librarian Positions in Academic Libraries? A Job Advertisement Analysis," The Journal of Academic Librarianship 35, no. 5 (2009): 457-67.

32. Carla J. Soffle and Kim Leeder, "Practitioners and Library Education: A Crisis of Understanding," Journal of Education for Library \& Information Science 46, no. 4 (2005): 312-19.

33. Marta Mestrovic Deyrup and Alan Delozier, "A Case Study on the Current Employment Status of New M.L.S. Graduates," Current Studies in Librarianship 25, no. 1/2, (2001): 21-38.

34. Mary A. Ball and Katherine Schilling, "Service Learning, Technology and LIS Education," Journal of Education for Library E Information Science 47, no. 4 (2006): 277-90.

35. Marta Mestrovic Deyrup and Alan Delozier, "A Case Study on the Current Employment Status of New M.L.S. Graduates," Current Studies in Librarianship 25, no. 1/2 (2001): 21-38.

36. Roy Tennant, "The Most Important Management Decision: Hiring Staff for the New Millennium," Library Journal 123, no. 3 (1998): 102. 